\title{
A new cyclodorippid crab, Berglundus bretoni n. gen., n. sp. (Decapoda, Cyclodorippidae), from the Northeastern Pacific, USA
}

Un nuevo cangrejo ciclodorípido, Berglundus bretoni n. gen., n. sp. (Decapoda, Cyclodorippidae), del noreste del Pacífico, EUA

Torrey Nyborg ${ }^{1}$, Alessandro Garassino ${ }^{1}$, Brant Nyborg ${ }^{1,2}$, Francisco J. Vega ${ }^{3, *}$

${ }^{1}$ Department of Earth and Biological Sciences, Loma Linda University, Loma Linda, CA 92350, USA.

24400 SW 179th Avenue, Aloha, Oregon 97078, USA.

${ }^{3}$ Instituto de Geología, Universidad Nacional Autónoma de México, Ciudad Universitaria, Coyoacán, CDMX, 04510, Mexico.

* Corresponding author: (F. J. Vega) vegver@unam.mx

\begin{abstract}
A new cyclodorippid crab, Berglundus bretoni n. gen., n. sp. (Cyclodorippidae Ortmann, 1892) from the Astoria Formation (early to middle Miocene) of Washington State is herein described. It represents the fourth genus of cyclodorippids in North America, keeping the stratigraphic range and the palaeogeographic distribution of the Cyclodorippidae unchanged.
\end{abstract}

Keywords: Crustacea, Cyclodorippoidea, Miocene, taxonomy, Washington State, USA.

\section{How to cite this article:}

Nyborg, T., Garassino, A., Nyborg, B., Vega, F.J., 2021, A new cyclodorippid crab, Berglundus bretoni n. gen., n. sp. (Decapoda, Cyclodorippidae), from the Northeastern Pacific,USA: Boletín de la Sociedad Geológica Mexicana, 73 (3), A301220. http://dx.doi. org/10.18268/BSGM2021v73n3a301220
Manuscript received: October 23, 2020

Corrected manuscript received: December 5, 2020

Manuscript accepted: December 15, 2020

Peer Reviewing under the responsibility of Universidad Nacional Autónoma de México.

This is an open access article under the CC BY-NC-SA license(https://creativecommons.org/licenses/by-nc-sa/4.0/)

\section{RESUMEN}

Un nuevo cangrejo ciclodorípido, Berglundus $\underline{\text { bretoni }}$ n. gen., n. sp. (Cyclodorippidae Ortmann, 1892) de la Formación Astoria (Mioceno temprano a medio) del Estado de Washington, es descrito aquí. Este es el cuarto género de ciclodorípidos en Norteamérica, manteniendo el alcance estratigráfico y paleobiogeográfico intactos.

Palabras clave: Crustacea, Cyclodorippoidea, Mioceno, taxonomía, Washington, EUA. 


\section{Introduction}

According to Guinot et al. (2013) the Section Cyclodorippoida Ahyong, Lai, Sharkey, Colgan and $\mathrm{Ng}, 2007$ includes 231 species within 46 genera, most of them extant. The fossil record of Cyclodorippoidae (Cyclodorippinae and Xeinostominae) is very scarce, restricted to only 4 genera with 10 species respectively (Schweitzer et al., 2017). Bishop (1983) described Hillius youngi Bishop, 1983 from the Early Cretaceous (Albian) of Texas (USA). Feldmann et al. (2011) reported Miotymolus quadratus Feldmann, Schweitzer, Casadío and Griffin, 2011 from the Miocene of Tierra del Fuego (Argentina). Tymolus Stimpson, 1858 is the best-known genus of the family with a widespread palaeogeographic distribution including 7 species from the Miocene to Pliocene of Alaska, Washington State, and Oregon (USA) and Japan (for complete list see Nyborg and Garassino, 2020). Finally, Schweitzer (2001) reported Xeinostoma antiqua Schweitzer, 2001 from the late Eocene (Priabonian) of Washington State (USA).

Subject of this note is the description of Berglundus n. gen. from the Astoria Formation (early to middle Miocene) of Washington State (USA), representing the fourth genus of cyclodorippids from North America. Based upon this new report, the stratigraphic range and palaeogeographic distribution of the Cyclodorippidae remains unchanged.

\section{Geological setting}

The Astoria Formation is widely distributed in southwestern Washington, with outcrops along the Columbia River, especially between the old townsite of Knappton on the west and Altoona to the east, outcrops along the Naselle River, and Salmon Creek, near the town of Naselle, and in southwestern Washington in the Montesano and Willapa Hills area (e.g., Weaver, 1937; Wolfe and Mckee, 1968, 1972; Wells, 1979, 1989; Logan, 1987; Walsh et al., 1987). This unit is part of a sequence of early to middle Miocene, terrestrial and marine beds of conglomerate, sandstone, and siltstone, exposed in the southwestern-most portion of Washington State, and tentatively correlated with the Astoria Formation of Oregon based upon faunal contents, stratigraphic position, and lithologic characteristics (e.g., Rau, 1948; Snaveley et al., 1978; Wolfe and Mckee, 1972; Walsh et al., 1987). The Astoria Formation of Washington locally interfingers with the Grande Ronde Basalt and the Wanapun Basalt of the Columbia River Basalt Group, which have been dated near the early-middle Miocene boundary (Walsh et al., 1987). Fossils within the Astoria Formation of Washington State appear to represent that part of the unit below these basalt flows, placing the fossil crabs described herein most likely within the early Miocene. Age control is also based upon mineral isotope composition (Wolfe and Mckee, 1972), the biostratigraphical distribution of molluscs (Etherington, 1931; Moore and Addicott, 1987), and Foraminifera (Rau, 1948). Although the fossil decapod crustacean faunas suggest a similarity in depositional environments and past workers have believed that rocks assigned to the Astoria Formation in Oregon and those in Washington State to be contemporaneous, there is a marked difference in fossil decapod crustacean faunas from the Astoria Formation of Oregon and Washington State, with only one genus, Mursia Leach in Desmarest, 1822, found in both States (Nyborg, 2002).

All of the specimens, except for one, as described herein, were collected from sandy-siltstone exposures on a west-facing road cut along Pigeon Point, along the north shore of the Columbia River, near the town of Altoona, Washington State (USA) (Figure 1). Weaver (1937) was the first to map the area of the Grays River Quandrangle that contains the Pigeon Point area. Wolfe and Mckee (1968) gave a detailed map of the area correlating the outcrops at Pigeon Point with the Astoria Formation. Berglund and Goedert (1992) were the first to describe a fossil crab Anisospinos wahkiakumensis (Berglund and Goedert, 1992) from this locality, providing faunal details of the locality and surrounding outcrops. Two other fossil crabs have also been described from this locality, 
Lophomastix altoonaensis Nyborg and Vega, 2008 and Macrocheira columbiaensis Nyborg, Nyborg, Garassino and Vega, 2016.

One additional specimen was collected from the stream gravels of Salmon Creek interpreted to have been derived from the Astoria Formation (Wolfe and Mckee, 1972) near the town of Naselle, Washington State, USA, in the NW1/4, NE1/4, T10N, R9W of the Knappton Quadrangle, Washington State-Oregon 7.5 minute series topographic map. Munida branti Nyborg and Garassino, 2015 is the only other fossil crab described from this locality.

Abbreviations: $L 1$, length of carapace; $W 1$, width of carapace; $W 2$, frontal width; $W 3$, fronto-orbital width; $W 4$, posterior width.

\section{Systematic palaeontology}

Section Cyclodorippoida Ahyong, Lai, Sharkey, Colgan and Ng, 2007

Superfamily Cyclodorippoidea Ortmann, 1892

Family Cyclodorippidae Ortmann, 1892

Subfamily Cyclodorippinae Ortmann, 1892

Genus Berglundus nov.

Diagnosis: Carapace subcircular and gently convex in both direction; rostrum tridentate, densely granular, axially depressed, ending into two small, sharp, triangular teeth forward directed; regions well defined and strongly inflated with 14 tubercles; anterolateral margin fringed with minute granules; smooth posterolateral margins.

Etymology: after Ross Berglund, deceased, who donated the studied specimens. Gender: masculine.

Type species: Berglundus bretoni n. gen., n. sp. by monotypy.

Discussion: Tavares (1993: 264) reported two families, Cyclodorippidae Ortmann, 1892 and Cymonomidae Bouvier, 1897, which are distinguished from each other by the difference in carapace outline and for the presence or absence of orbits.

Later, Tavares (1998) described the new family Phyllotymolinidae, including three extant genera. Finally Frantescu (2014) described the new family Quadratoplanidae, including just one sole genus from the Early Cretaceous (Albian) of Texas (USA). Although the studied specimens do not preserve ventral parts, useful diagnostic characters in the systematics of the Cyclodorippoidea, they can be assigned to the Cyclodorippidae for the subcircular carapace, the presence of orbits, and well-defined and inflated carapace regions. Indeed, we exclude their belonging to the Cymonomidae having subsquare carapace and absence of orbits.

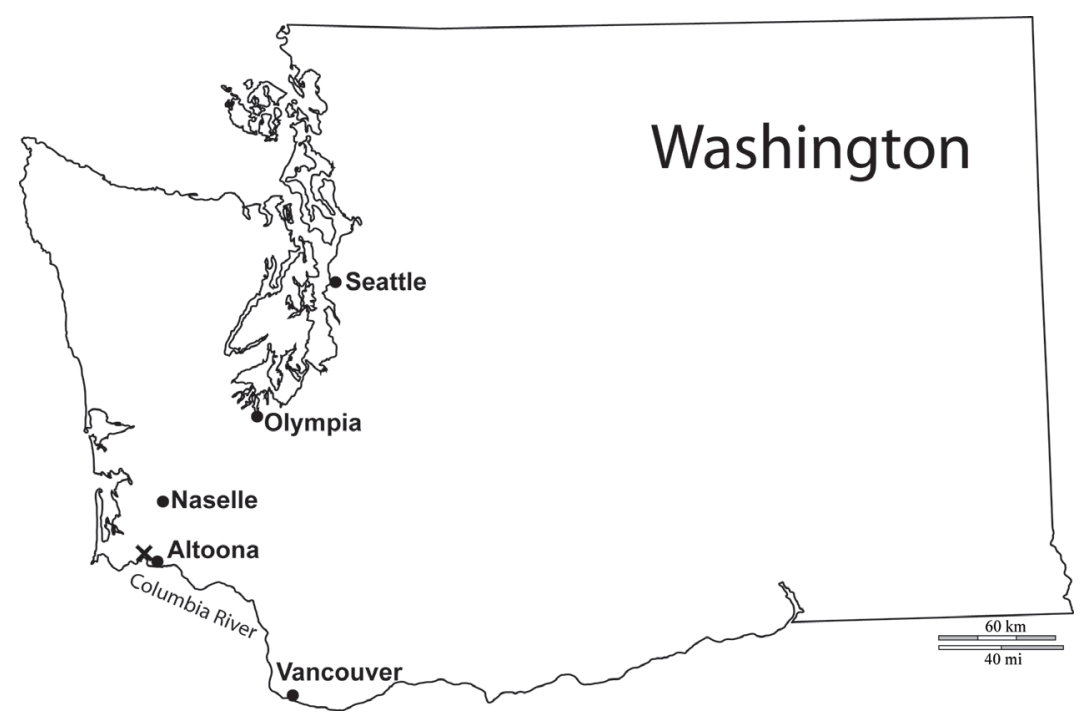

Figure 1 Map drawing showing the approximate locality (X) where Berglundus bretoni n. gen., n. sp. was collected. 
The carapace regions scarcely defined and inflated distinguish the Phyllotymolinidae from the studied specimens. Finally, the rectangular outline of the carapace and the flat and moderately developed carapace regions also distinguish the studied specimens from the Quadratoplanidae.

Based upon Schweitzer et al. (2017) the Cyclodorippinae includes three genera: Hillius Bishop, 1983 (fossil); Miotymolus Feldmann, Schweitzer, Casadío and Griffin, 2011 (fossil); and Tymolus Stimpson, 1858 (extant and fossil).

The tridentate rostrum, ending in two small, sharp, triangular teeth and the carapace regions strongly inflated with 14 tubercles distinguish the studied specimens from Hillius having a wide front and carapace regions not inflated and scarcely tuberculate (except protogastric and cardiac regions with one and two tubercles respectively); and from Miotymolus having a bifid rostrum and inflated carapace regions without tubercles.

The studied specimens share with Tymolus the granulate and inflated carapace regions with tubercles in some fossil species, like T. bottemilleri Nyborg and Garassino, 2020 or T. collinsi Nyborg and Garassino, 2020, and well marked by deep grooves. However, the tridentate rostrum, ending in two small, sharp, triangular teeth distinguishes the studied specimens from Tymolus having a bifid rostrum.

The shape of the rostrum of the studied specimens is unique among the fossil genera of the Cyclodorippinae, although the distinct rostral shape, as proven by some extant genera of the subfamily, such as Coricodus A. Milne-Edwards, 1880, Clythrocerus A. Milne-Edwards and Bouvier, 1899, and Deilocerus Tavares, 1993, include species having a highly variable rostral shape (Goeke and Heard, 1984; Tavares, 1993).

In conclusion, we justify the description of the new genus Berglundus for tridentate rostrum and the inflated carapaces regions with 14 tubercles, which are unique among the representatives of the Cyclodorippidae.

Berglundus bretoni $\mathrm{n}$. gen., n. sp.

(Figures 2 and 3)
Diagnosis: As for the genus.

Etymology: after Gerard Breton (1944-2019) for his important contribution to the knowledge of Cenozoic fossil crabs.

Type material: Holotype UWBM IP 97181, and paratypes UWBM IP 97182-97193 (UWBM IP $=$ The Burke Museum of Natural History and Culture, Invertebrate Paleontology Collections, University of Washington, Seattle, Washington State, USA).

Geological age: early to middle Miocene, Astoria Formation.

Measurements: (in mm) Holotype UWBM IP 97181, $L 1=10.2, W 1=10.2, W 2=1.1, W 3$ $=2.7, W 4=5.8$. Paratype UWBM IP 97185, L1 = approximately 10.9, W1 $=11.1, W 2=1.8, W 3$ = 4.4. Paratype UWBM IP 97186, $L 1=$ approximately $12.8, W 1=12.8, W 2=2.5, W 3=5.0, W 4$ $=7.1$. Remainder of paratype specimens only partially preserved.

Occurrence: The holotype UWBM IP 97181 and paratypes UWBM IP 97182-97192 were collected from concretions along Pigeon Point, along the north shore of the Columbia River, near the town of Altoona, Washington State (Figure 1). Paratype UWBM IP 97193 was collected from a concretion as float along Salmon Creek, near the town of Naselle. Specimen UWBM IP 97193 is only partially preserved, however dorsal carapace regions match that of the other specimens collected at Pigeon Point.

Description: Carapace subcircular, weakly vaulted transversely and longitudinally, length about 96 percent maximum carapace width; regions strongly inflated, delineated by deep grooves; carapace surface granular, almost pustulose on tubercles and frontal region, remainder of surface smooth; rostrum tridentate, densely granular, axially depressed, ending in two small, sharp, triangular spines directed forward (see Figure 2E: spine 3); pair of spines on either side, rounded, triangular, sharp, laterally directed, separated from medial spines by shallow U-shaped notch (see Figure 2E: spine 2); inner-orbital spines large, rounded, inflated, separated from adjacent spines by a deep U-shaped notch (see Figure 2E: 


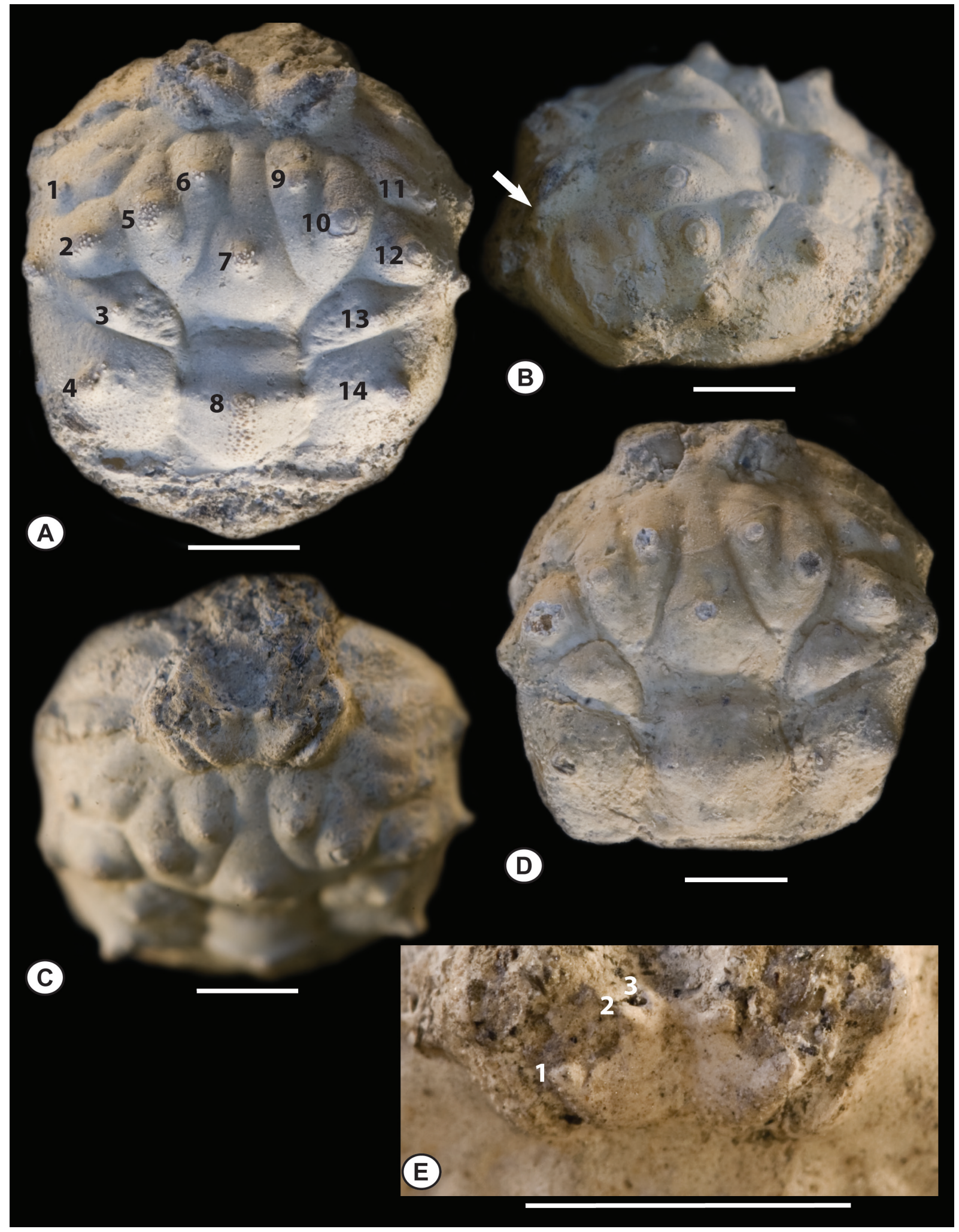

Figure 2 Berglundus bretoni n. gen., n. sp., A) Holotype, UWBM IP 97181, general view of carapace dorsal surface. Numbers 1-14 represent placement of the fourteen carapace tubercles. B) Holotype, UWBM IP 97181, right-lateral view of carapace. Arrow indicates outer-orbital spine. C) Holotype, UWBM IP 97181, close-up view of rostrum. D) Paratype UWBM IP 97185, general view of carapace dorsal surface. E) Holotype, UWBM IP 97181, close-up view of rostrum with numbers indicating the three spines of the rostrum. Scale bar equals 5 mm. 


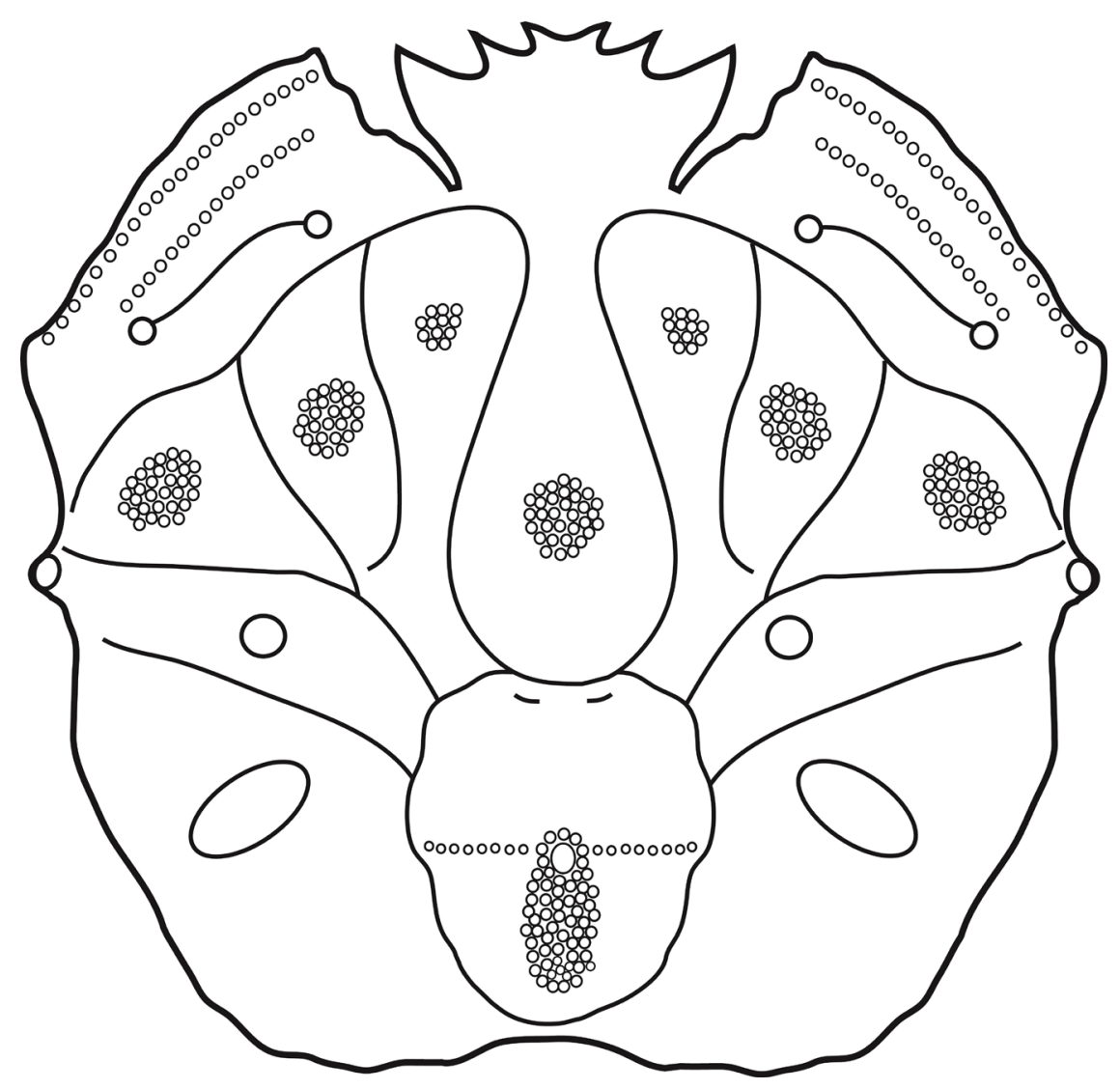

Figure 3 Idealized line drawings of Berglundus bretoni n. gen., n. sp. discussed herein. Line drawing not drawn to scale.

spine 1); frontal width about 15 percent maximum carapace width; orbits deep, longitudinally narrow; outer-orbital spine broadly triangular, weakly projected; fronto-orbital width occupying 35 percent maximum carapace width; anterolateral margin strongly convex nearly vertical, fringed with minute granules; anterolateral margin with two rounded spines, one situated along lateral margin of subhepatic region, second one along lateral margin of epibranchial region; smooth posterolateral margin rounded, tapering posteriorly; posterior margin medially concave, rimmed; subhepatic and suborbital regions inflated, separated by deep grooves; subhepatic ridges with a row of small tubercles, directed axially, weakly curving forward; small, rectangular hepatic region, transversely elongate, separated by sinuous, deep groove posteriorly and divided by shallow groove; anterior and axial portion largest with longitudinally inflated tuber- cle; small posterior portion with small, rounded tubercle; epigastric region transversely depressed, poorly defined; groove extends transversely, ending at base of outer-orbital spine; protogastric region longitudinally inflated, weakly triangular rounded, divided in half by a shallow, narrow, longitudinal groove, directed axially; protogastric region with one rounded, anterior tubercle and one posterior tubercle slightly larger than anterior one; triangular-shaped mesogastric region, narrow anteriorly, wider posteriorly with an axially median rounded tubercle; smooth depressed metagastric region with two deep gastric pits; rectangular urogastric region inflated only about half as much as other axial regions, defined by posterior depression and anterior and lateral grooves; rounded, weakly subpentagonal cardiac region; anterior transversely ridged with one median turbercle axially situated on anterior margin of region; granules on and axi- 
ally of cardiac tubercle; intestinal region strongly reduced, not well differentiated; epibranchial region divided in two parts by deep groove; anterior separated by deep cervical groove; posterior by deep, narrow branchiocardiac groove; anterior portion quadrate, strongly inflated, with one large, rounded, median tubercle; triangular-shaped posterior portion, strongly inflated with one median tubercle; mesobranchial region with one median tubercle; smooth metabranchial region; sternum and appendages not preserved.

\section{Conclusion}

The fossil record of the Cyclodorippidae includes four genera Hillius Bishop, 1983 (fossil), Miotymolus Feldmann, Schweitzer, Casadío and Griffin, 2011 (fossil), Tymolus Stimpson, 1858 (fossil and extant), and Xeinostoma Stebbing, 1920 (fossil and extant) reported from the Early Cretaceous (Albian) to the Miocene of North and South America and Japan, suggesting that the cyclodorippids had an amphitropical distribution in the Miocene and the origin of the family most likely predated that time (Feldmann et al., 2011). Based upon Tavares (1993, 1996) the Cyclodorippidae presently has a broad geographic range extending from northern Japan through the Indian Ocean and south to Tasmania in the Indo-West Pacific region and from the United States to northern Brazil. The extant representatives of the family in the Indo-West Pacific have usually a small-sized body (Davie, 2002; Poore, 2004) living at depths ranging from 90-1200 m. and typically inhabit soft, sandy, and muddy substrates (Davie, 2002). Fossil cyclodorippids reported from the Miocene of Japan, Alaska, and Washington State (Imiazumi, 1952; Takeda and Tomida, 1984; Conkle et al., 2006; Nyborg and Garassino, 2020) and assigned to Tymolus are larger than the extant forms. Schweitzer (2001) described Xeinostoma antiqua from the late Eocene of Washington State based upon one incomplete sole specimen, which is as small as the extant representatives of the genus.

\section{Acknowledgements}

We wish to thank R. Berglund, deceased, for donating specimens described herein from Pigeon Point and V. Nyborg for collection of additional specimens from the Pigeon Point locality. We also thank H. Karasawa (Mizunami Fossil Museum, Yamanouchi, Akeyo, Mizunami, Gifu, Japan) and G. Schweigert (Staatliches Museum für Naturkunde, Stuttgart, Germany) for their comments and suggestions in making this manuscript ready for publication.

\section{References}

Ahyong, S., Lai, J.C.Y., Sharkey, D., Colgan, D.J., Ng, P.K.L., 2007, Phylogenetics of the brachyuran crabs (Crustacea: Decapoda): The status of Podotremata based on small subunit nuclear ribosomal RNA: Molecular Phylogenetics and Evolution, 45(2), 576-86. https://doi.org/10.1016/j. ympev.2007.03.022

Berglund, R.E., Goedert J.L., 1992, A new species of Cancer (Decapoda: Brachyura) from the Miocene Astoria Formation in Washington: Burke Museum Contributions in Anthropology and Natural History, 9, $1-11$.

Bishop, G.A., 1983, Fossil decapod crustaceans from the Lower Cretaceous, Glen Rose Limestone of central Texas: Transactions of the San Diego Society of Natural History, 20, 27-55. https://doi.org/10.5962/bhl. part.28997

Bouvier, E.L., 1897, Sur la classification, les origines et la distribution des Crabes de la famille des Dorippidés: Bulletin de la Société philomathique de Paris, 8(9), 54-70.

Conkle, L.N., Schweitzer, G.E., Feldmann, R.M., Blodgett, R.B., 2006, A new species of Tymolus and a report on Metacarcinus from the Miocene of Alaska: Bulletin of the Mizunami Fossil Museum, 33, 47-57. 
Davie, P.J.F., 2002, Crustacea: Malacostraca: Eucarida (Part 2), Decapoda-Anomura, Brachyura, in Wells, A., Houston, W.W.K. (eds), Zoological catalogue of Australia, Vol. 19.3B, C.SIRO Publishing, Australia. 641 p.

Desmarest, A. G., 1822, Les crustacés proprement dits, in Brogniart, A., Desmarest, A.-G. (eds.), Histoire naturelle des crustacés fossiles sous les rapports zoologique et géologiques. F.G. Levrault, Paris, 67-142.

Etherington, T.J., 1931, Stratigraphy and fauna of the Astoria Miocene of southwest Washington: Bulletin of the Department of Geology of the University of California, 20(5), 31-142.

Feldmann, R.M., Schweitzer, G.E., Casadío, S., Griffin, M., 2011, New Miocene Decapoda (Thalassinidea; Brachyura) from Tierra del Fuego, Argentina: Paleobiogeographic implications: Annals of Carnegie Museum, 79(2), 91-123. https://doi. org/10.2992/007.079.0202

Frantescu, O., 2014, Fossil decapods from the Cretaceous (late Albian) of Tarrant County, Texas: Neues Jahrbuch für Geologie und Paläontologie, Abhandlungen, 273(3), 221-239. https://doi. org/10.1127/0077-7749/2014/0427

Goeke, G.D., Heard, R.W.Jr, 1984, A review of the genus Clythrocerus (Brachyura: Dorippidae) in the eastern Gulf of Mexico with notes on Clythrocerus stimpsoni: Gulf Research Reports, 7(4), 351-355. https://doi.org/10.18785/ grr.0704.06

Guinot, D., Tavares, M., Castro, P., 2013, Significance of the sexual openings and supplementary structures on the phylogeny of brachyuran crabs (Crustacea, Decapoda, Brachyura), with new nomina for higherranked podotreme taxa: Zootaxa, 3665 (1), 1-414. https://doi.org/10.11646/ zootaxa.3665.1.1

Imiazumi, R., 1952, A Miocene crab, Tymolus kamadai n. sp. from the Numanouchi Formation of the Joban Coal-field:
Transactions and Proceedings of the Palaeontological Society of Japan, 7, 201-204.

Logan, R.L., 1987, Geologic map of the Chehalis River and Westport quadrangles, Washington: Washington Division of Geology and Earth Resources Open File Report 87-8, 17 p., 1 plate, scale 1:100,000.

Milne-Edwards, A., 1880, Études préliminaires sur les Crustacés, lère Partie, in Reports on the Results of Dredging under the Supervision of Alexander Agassiz, in the Gulf of Mexico, and in the Caribbean Sea, 1877, 1878, 1879, by the U. S. Coast Survey Steamer "Blake", Lieut-Commander C. D. Sigsbee, U.S.N., and Commander J.R. Bartlett, U.S.N., Commanding: Bulletin of the Museum of Comparative Zoology Harvard, 8(1), 1-68.

Milne-Edwards, A., Bouvier, E.-L., 1899, Les Dromiacés et Oxystomes, in Reports on the Results of Dredging under the Supervision of Alexander Agassiz, in the Gulf of Mexico, and in the Caribbean Sea, 1877, '78, '79, by the U.S. Coast Survey Steamer "Blake.": Memoirs of the Museum of Comparative Zoology, 27, 1-127.

Moore, E. J., Addicott, W.O., 1987, The Miocene Pillarian and Newportian (molluscan) stages of Washington and Oregon and their usefulness in correlations from Alaska to California: U.S. Geological Survey Bulletin, 1664, 13 p.

Nyborg, T.G., 2002, Fossil decapod crustaceans from the early to middle Miocene Astoria Formation, Washington and Oregon, U.S.A., Unpublished Master's thesis, Kent State University, Kent, Ohio, 224 p.

Nyborg, T., Garassino, A., 2015, New fossil squat lobsters (Crustacea: Anomura: Munididae) from the Eastern Pacific: Palaeodiversity, 8, 95-101.

Nyborg, T., Garassino, A., 2020, New Neogene species of Tymolus Stimpson, 1858 (Decapoda, Brachyura, Cyclodorippidae) from the eastern Pacific: Neues Jahrbuch für 
Geologie und Paläontologie, Abhandlungen, 296(1-2), 167-174. https://doi.org/10.1127/ njgpa/2020/0901

Nyborg, T., Nyborg, B., Garassino, A., Vega, F.J., 2016, New occurrences of fossil Macrocheira (Brachyura, Inachidae) from the North Eastern Pacific: Paleontología Mexicana, 5(2), 123-135.

Nyborg T., Vega F.J., 2008, Three new fossil species of Lophomastix (Decapoda: Blepharipodidae) from the Cenozoic of Washington: Journal of Crustacean Biology, 28(2), 361-369. https://doi. org/10.1651/0278-0372(2008)028[0361:tnf sol]2.0.co;2

Ortmann, A., 1892, Die Dekapoden-Krebse des Strassburger Museums V. Die Abtheilungen Hippidae, Dromiidae, und Oxystomata: Zoologische Jahrbücher, Abtheilung für Systematik, Geographie und Biologie der Thiere, 6, 532-588. https://doi. org/10.5962/bhl.title. 15948

Poore, G.C.B., 2004, Marine Decapod Crustacea of Southern Australia. CSIRO Publishing, Australia. 574 p.

Rau, W.W., 1948, Foraminifera from the Miocene Astoria Formation in southwestern Washington: Journal of Paleontology, 22(6), 774-782.

Snavely, P.D. Jr., Niem, A.R., Pearl, J.E., 1978, Twin River Group (Upper Eocene to Lower Miocene) - defined to include the Hoko River, Makah, and Pyshy Formations, Clallam County, Washington, in Sohl, N.F., Wright, W.B. (eds.), Changes in stratigraphic nomenclature by the U.S. Geological Survey, 1977: U. S. Geological Survey Bulletin, 1457A, A111-A120.

Schweitzer, G.E., 2001, Additions to the Tertiary decapod fauna of the Pacific Northwest of North America: Journal of Crustacean Biology, 21(2), 521-537. https://doi. org/10.1651/0278-0372(2001)021[0521:attt df]2.0.co;2

Schweitzer, C.E., Feldmann, R.M., Karasawa, H., 2017, Part R, Revised, Volume 1, Chapter
8R: Systematic descriptions: Section Cyclodorippoida: Treatise Online, 97, 1-6. https://doi.org/10.17161/to.v0i0.6659

Stebbing, T.R.R., 1920, South African Crustacea (Part X of S. A. Crustacea, for the Marine Investigations in South Africa): Annals of the South African Museum, 17(4), 231-272. https://doi.org/10.5962/ bhl.part. 22316

Stimpson, W., 1857-1860, Prodromus descriptionis animalium evertebratorum, quae in Expeditione ad Oceanum Pacificum Septentrionalem, a Republica Federata missa, Cadwaladaro Ringgold et Johanne Rodgers Ducibus, observavit et Descripsit: Proceedings of the Academy of Natural Sciences of Philadelphia, Crustacea Maioidea, 9(3), 216-221.

Takeda, M., Tomida, S., 1984, Two New Fossil Crabs of the Tymolidae from the Miocene Mizunami group, Central Japan: Bulletin of the Mizunami Fossil Museum, 11, 39-48.

Tavares, M., 1993, Crustacea Decapoda: les Cyclodorippidae et Cymonomidae de l'Indo-Ouest-Pacifique à l'exclusion du genre Cymonomus, in Crosnier, A. (ed.), Résultats des Campagnes MUSORSTOM, volume 10: Mémoires du Muséum national d'Histoire naturelle, 156, 253-313.

Tavares, M., 1996, Révision systématique des Cyclodorippidae américains (Crustacea, Decapoda, Brachyura): Bulletin du Muséum national d'Histoire naturelle, 4 série, 18(1-2), 233-295.

Tavares, M., 1998, Plyllotymolinidae, nouvelle famille de Brachyoures Podotremata (Crustacea, Decapoda): Zoosystema, 20(1), 109-122.

Walsh, T.J., Korosec, M.A., Phillips, W.M., Logan, R.L., Schasse, H.W., 1987, Geologic map of Washington - southwest quadrant: Washington Division of Geology and Earth Resources Geologic Map GM34, scale 1:250,000.

Weaver, C.E., 1937, Tertiary stratigraphy of western Washington and northwestern 
Oregon: University of Washington Publications in Geology, 4, 1-266.

Wells, R.E., 1979, Geologic map of the Cape Disappointment-Naselle River area, Pacific County, Washington: U.S. Geologic Survery Open-File Report, 79-389.

Wells, R.E., 1989, Geologic map of the Cape Disappointment - Naselle River area, Pacific and Wahkiakum Counties, Washington. USGS Numbered Series, IMAP 1832, Scale 1: 62,500 .
Wolfe, E.W., McKee, E.H., 1968, Geology of the Grays River quadrangle, Wahkiakum and Pacific Counties, Washington: Washington State Department of Natural Resources Division of Geology and Earth Resources, Geologic Map GM-4.

Wolfe, E.W., McKee, E.H., 1972, Sedimentary and igneous rocks of the Grays River quadrangle, Washington: U. S. Geologic Survery Bulletin, 1335, 1-70. https://doi. org/10.3133/b133 